\title{
Faktor - Faktor Penghambat Penerapan Analisis Standar Belanja (ASB) Pada Pemerintah Kota Kotamobagu
}

\author{
REINCE HERRY TANGKOWIT ${ }^{1}$, LINTJE KALANGI ${ }^{2}$, LINDA LAMBEY ${ }^{3}$ \\ 1,2,3 Program Magister Akutansi, Fakultas Ekonomi dan Bisnis Universitas Sam Ratulangi \\ email : reins.tangkowit@gmail.com ${ }^{1}$, lintjekalangi@yahoo.com ${ }^{2}$, lindalambey@yahoo.com ${ }^{3}$
}

\begin{abstract}
Implementation of Expenditure Standards Analysis (ASB) is known having an important role as the requirement to analyze the budget expenditure reasonableness review on each Programs/ Activities held by units on a year. Kotamobagu local government has not applied the ASB yet. This study is intended to analyze the inhibiting factors on Standards Analysis Expenditure (ASB) implementation in Local Government of Kotamobagu. The research method used in this research is a qualitative exploratory approach. Data were collected by in-depth interviews, observation, and document study. The key informants were purposively determined to get the right information accurately. In-depth interviews were conducted by using semi-structured interviews for 45 to 60 minutes. Triangulation method was used to test the validity or credibility of data and resources. Transcripts data which transcribed from the interviews were analyzed by using content analysis method. Themes or codes were established from the data transcription. The results show that there are several inhibiting factors in implementing the ASB in Kotamobagu local Government. There were 6 of inhibiting factors: (1) legal basis, (2) ineffectiveness of ASB and difficult to understand, (3) communication, (4) dispositions / attitudes, (5) human resources, (6) the role of TAPD (Budget Team Local Government).
\end{abstract}

Keywords: Expenditure Standards Analysis, Performance-Based Budgeting, Regional Government Budget, Local Government Financial Management.

Abstrak. Penerapan Analisis Standar Belanja (ASB) diketahui berperan penting sebagai syarat yang digunakan untuk menganalisis kewajaran anggaran belanja setiap program/kegiatan yang dilaksanakan oleh Satuan Kerja Perangkat Daerah (SKPD) dalam satu tahun anggaran. Pemerintah Kota Kotamobagu belum menerapkan ASB. Penelitian ini bertujuan menganalisis apa faktor-faktor penghambat penerapan ASB pada Pemerintah Kota Kotamobagu. Metode penelitian menggunakan kualitatif dengan pendekatan eksploratori dan Pemerintah Kota Kotamobagu sebagai objek penelitian. Data diperoleh melalui teknik wawancara mendalam, pengamatan, dan studi dokumentasi. Informan kunci ditentukan secara purposif untuk mendapatkan hasil informasi yang tepat dan akurat. Wawancara menggunakan In-depth interview jenis semi terstruktur selama 45 hingga 60 menit. Metode triangulasi digunakan dalam pengujian validitas atau kredibilitas data dan sumber. Data transkrip yang ditranscribe dari hasil wawancara dianalisis dengan metode analisis isi kemudian diberi tema/coding dan dilakukan konseptualisasi pernyataan ilmiah. Hasil interpretasi disimpulkan dalam teks naratif. Hasil penelitian menunjukkan ada beberapa faktor penghambat penerapan ASB pada Pemerintah Kota Kotamobagu. Ada 6 faktor penghambat : (1) dasar hukum, (2) ASB tidak efektif dan sulit dipahami, (3) komunikasi, (4) disposisi/sikap, (5) sumber daya manusia, (6) peran TAPD.

Kata Kunci : Analisis Standar Belanja, Anggaran Berbasis Kinerja, Anggaran Pendapatan dan Belanja Daerah, Pengelolaan Keuangan Daerah.

\section{Pendahuluan}

Dalam memenuhi semakin meningkat-nya tuntutan transparansi dan akuntabilitas atas pengelolaan keuangan daerah secara ekonomis, efisien, dan efektif (value for money), cara yang dilakukan oleh pemerintah daerah adalah dengan menggunakan analisis standar 
belanja (ASB). Dalam Peraturan Pemerintah Nomor 58 Tahun 2005 Tentang Pengelolaan Keuangan Daerah menyebutkan penyusunan anggaran berdasarkan prestasi kerja dilakukan berdasarkan capaian kinerja, indikator kinerja, analisis standar belanja, standar satuan harga, dan standar pelayanan minimum. Di antara komponen-komponen anggaran berbasis kinerja (ABK), Indikator Kinerja, Standar Pelayanan Minimum, dan ASB menjadi instrumen penganggaran yang sangat penting karena adanya ketidakadilan dan ketidakwajaran anggaran belanja antar kegiatan sejenis antar program dan antar SKPD, yang disebabkan oleh : (1) Tidak jelasnya definisi suatu kegiatan, (2) Perbedaan output kegiatan, (3) Perbedaan lama waktu pelaksanaan, (4) Perbedaan kebutuhan sumberdaya, (5) Beragamnya perlakuan objek atau rincian objek belanja (Tanjung 2010:1). Penyebab tersebut dapat diidentifikasikan sebagai bagian dari ciri-ciri anggaran tradisional yang disusun atas dasar pendekatan incremental dan line-item.

Dalam reviu perencanaan dan penganggaran Inspektorat Jenderal Kementerian Dalam Negeri 2016, Tarmizi A. Karim menyatakan bahwa permasalahan dalam penganggaran saat ini adalah Rencana Kerja dan Anggaran Satuan Kerja Perangkat Daerah (RKA-SKPD) belum konsisten terhadap kaidah-kaidah perencanaan dan belum disusun dengan baik dan tepat sesuai dengan kaidah-kaidah penganggaran serta Informasi dalam dokumen RKA-SKPD kerapkali tidak terukur dan melenceng dari tujuan yang direncanakan.

Penelitian Nabila (2014:541) mengata-kan bahwa biaya (pengeluaran) yang digunakan untuk mendanai output belum menggunakan metode perhitungan biaya yang memadai atau belum menggunakan costing system yang jelas. Berbeda dengan praktek yang ada disektor privat dimana penetapan harga standar dihitung dari data masa lalu yang dihasilkan oleh sistem akuntansi dan disesuaikan dengan metode

costing system, seperti activity based costing.

Berdasarkan latar belakang masalah, dapat ditarik kesimpulan bahwa Pemerintah Daerah masih memiliki kelemahan dalam sistem penganggaran dan kinerja pengelolaan keuangan mengakibatkan inefesiensi, inefektivitas dan rendahnya akuntabilitas publik. Agar supaya pengeluaran anggaran berdasarkan pada kewajaran ekonomi, efisien dan efektif (value for money), maka pemerintah perlu menerapkan sistem penganggaran yang disusun berdasarkan pendekatan anggaran kinerja (performance budget).

Maharshiyam (2015:2) dalam peneli-tiannya menyatakan bahwa kota-kota di Indonesia pun masih banyak yang melakukan sosialisasi ASB, padahal aturan mengenai ASB sudah lama dikeluarkan oleh Indonesia. Maharshiyam (2015:12) juga mengemukakan faktorfaktor penghambat penerapan ASB disebabkan oleh kelengkapan dasar hukum, kemampuan sumber daya manusia dan koordinasi antar stakeholder.

Kegiatan penelitian yang dilakukan oleh peneliti, diketahui bahwa Kota Kotamobagu sudah memiliki model ASB hasil kerja sama dengan Program Magister Akuntansi Universitas Sam Ratulangi pada tahun 2014, tujuannya untuk mengukur kewajaran belanja setiap program dan kegiatan yang disusun oleh SKPD. Ada 6 (enam) program/kegiatan model ASB yang dihasilkan: (1) Rapat-Rapat Konsultasi dan Koordinasi ke Luar Daerah, (2) Bimbingan non Teknis, (3) Sosialisasi, (4) Forum Kerjasama, (5) Peningkatan Sumber Daya Manusia, dan (6) Laporan Monitoring dan Evaluasi. Akan tetapi sampai saat ini model ASB tersebut belum ditindaklanjuti penerapannya dengan Peraturan Kepala Daerah oleh karena Kota Kotamobagu sudah ketiga kalinya mendapatkan opini WTP atas laporan keuangannya dan proses penyusunan anggaran sudah mulai menggunakan sistem informasi e-government.

Tujuan yang ingin dicapai dalam penelitian ini adalah untuk menganalisis faktor-faktor apa yang menghambat penerapan ASB pada Pemerintah Kota Kotamobagu dan bagaimana peranan ASB pada Pemerintah Kota Kotamobagu. 


\section{Model Analisis}

Model analisis pada penelitian ini dimulai dengan telaah paradigma melalui kajian isuisu empirik tentang pengelolaan keuangan daerah, menentukan topik penelitian yaitu anggaran berbasis kinerja dengan konsep 3E (ekonomis, efisien, efektif) dengan semua elemen didalamnya, dapat dilihat pada Gambar 1.

\section{Metode Penelitian}

Penelitian ini menggunakan metode penelitian kualitatif dengan pendekatan eksploratori (exploratory approach). Creswell (2012:206) menjelaskan bahwa dalam penelitian kualitatif, tujuannya adalah tidak untuk menggeneralisasi ke populasi, tetapi untuk mengembangkan eksplorasi men-dalam terhadap inti fenomena.

Gambar 1. Model Analisis

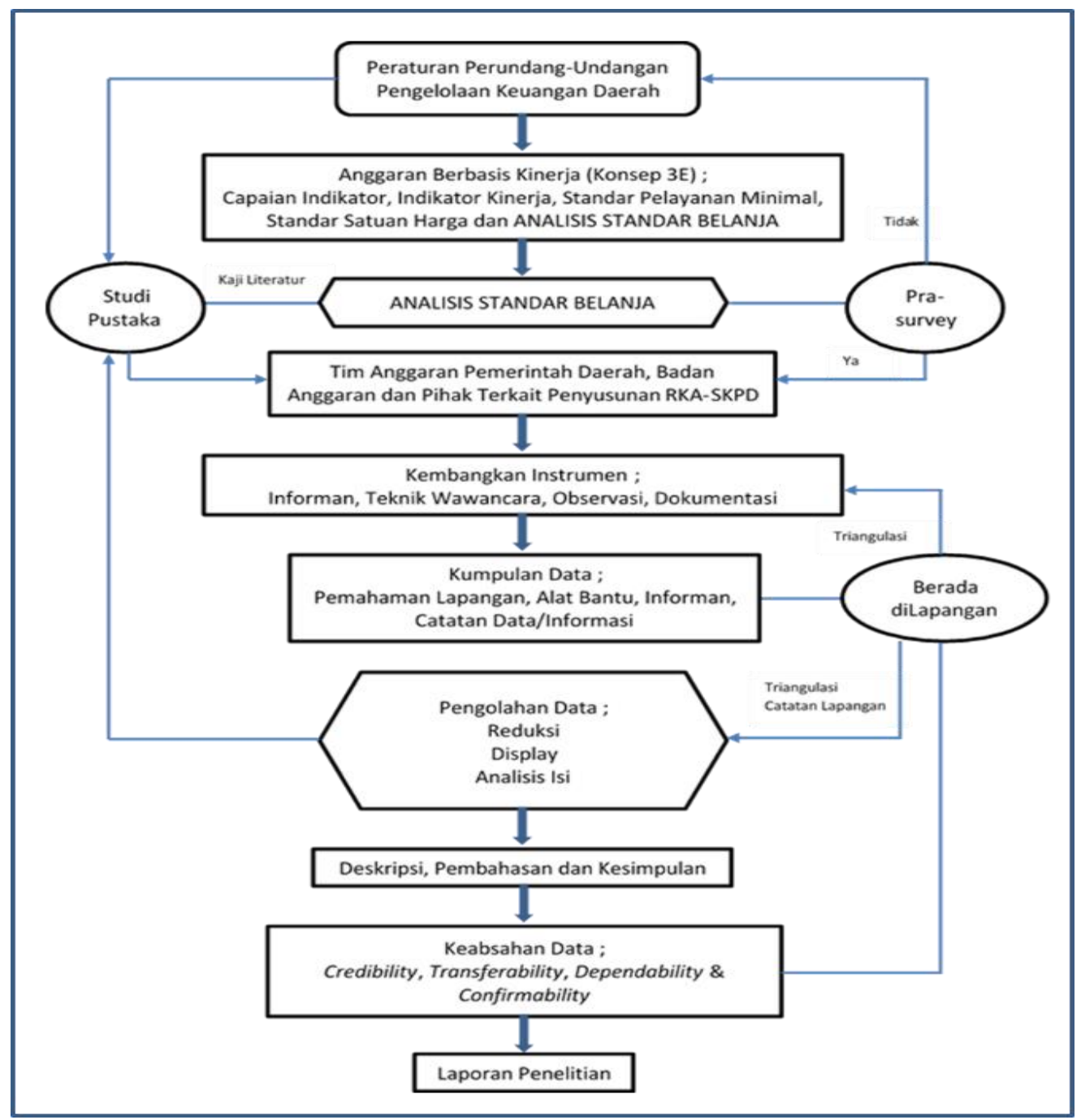

Pendekatan eksploratori dalam penelitian kualitatif adalah cara kerja penelitian yang dimaksudkan untuk menemukan lebih jauh dan mendalam terhadap kemungkinankemungkinan lain dari permasalahan yang diteliti (Ibrahim 2015:64).

Teknik pengumpulan data yang ditempuh dalam penelitian ini adalah melalui pengamatan/observasi (observation), wawancara mendalam (indepth interview), dan dokumentasi (documentation). Selan-jutnya, uji keabsahan data dalam penelitian kualitatif meliputi uji credibility (validitas internal), transferability (validitas eksternal), dependability (reliabilitas) dan confirmability (objektivitas). 
Metode analisis data yang dipakai adalah content analysis (analisis isi). Metode ini merupakan bagian dari metode analisis teks dan bahasa (Satori dan Komariah, 2014:202). Content analysis digunakan untuk menganalisis data interview transcription yang ditranscribe dari hasil wawancara. Langkah selanjutnya aktivitas analisis data Miles and Huberman (1984) dalam Satori dan Komariah (2014:218) terdiri atas: data reduction, data display dan conclusion drawing/verification yang dilakukan secara interaktif dan berlangsung secara terus menerus sampai tuntas, sehingga datanya mencapai jenuh. Analisis data yang dikembangkan pada penelitian ini adalah dengan editing, kategorisasi/coding dan meaning (Musfiqon, 2012).

\section{Analisis dan Pembahasan}

Penelitian ini dilakukan selama 3 (tiga) bulan yakni antara bulan November 2016 hingga bulan Januari 2017. Intrumen penelitian pendukung adalah buku catatan (notebook), pedoman wawancara, instru-men observasi lapangan, alat perekam berupa audio/video recorder (handycam) untuk merekam pelaksanaan wawancara dengan informan yang hasilnya di-transcribe menjadi transkrip data, kamera untuk mendokumentasikan kegiatan penelitian dilapangan, laptop untuk menunjang penulisan hasil penelitian dan ditunjang pengalaman peneliti yang sebelum bekerja sebagai fungsional umum di Badan Perencanaan Pembangunan Daerah Kota Kotamobagu selama 3 (tiga) tahun.

\section{Peranan ASB}

ASB berperan penting dalam proses penganggaran guna meningkatnya tuntutan transparansi dan akuntabilitas atas pengelolaan keuangan daerah secara ekonomis, efisien, dan efektif (value for money). Salah satu cara yang dilakukan oleh Pemerintah Kota Kotamobagu adalah dengan menggunakan prinsip ASB walaupun secara formal ASB belum diterapkan sebagaimana diamanatkan oleh peraturan perundang-undangan. Hasil analisis dan pembahasan tentang peranan ASB di Kota Kotamobagu dapat dilihat pada tabel 1. Selanjutanya hasil tersebut dilakukan konseptualisasi ilmiah. Data memperjelas bahwa peranan ASB dalam proses penganggaran itu sangat penting.

Tabel 1. Peranan ASB Di Kota Kotamobagu

\begin{tabular}{|l|l|}
\hline \multicolumn{1}{|c|}{ Rumusan Masalah } & \multicolumn{1}{|c|}{ Hasil Analisis dan Pembahasan } \\
\hline Bagaimana peranan & Dari hasil analisis dan pembahasan tentang peranan ASB yang ditemukan: \\
Analisis Standar & 1. Manfaat Analisis Standar Belanja (ASB) agar anggaran efisien dan efektif. \\
Belanja (ASB) Pada & 2. Satuan Kerja Perangkat Daerah (SKPD) yang seharusnya berperan melaksanakan \\
Pemerintah Kota & ASB dengan arahan TAPD. \\
Kotamobagu? & $\begin{array}{l}\text { 3. } \begin{array}{l}\text { Dengan adanya ASB penyusunan RKA-SKPD akan lebih cepat dari pada sebelum } \\
\text { diterapkan ASB. }\end{array} \\
\text { 4. Tahapan pembahasan RKA -SKPD sampai Raperda APBD sering terlambat dari } \\
\text { waktu yang ditetapkan. Dengan adanya ASB bisa memperbaiki Administrasi lebih } \\
\text { tertib. }\end{array}$ \\
& $\begin{array}{l}\text { Karena pentingnya ASB, Pemerintah Kota Kotamobagu melakukan kerjasama } \\
\text { dengan Universitas Sam Ratulangi untuk menyusun model ASB dan hasilnya } \\
\text { belum diterapkan. }\end{array}$ \\
\hline
\end{tabular}

Sumber : Data hasil olahan, 2017.

Menurut Peraturan Menteri Dalam Negeri No. 13 Tahun 2006 bahwa ASB sebagai salah satu syarat dalam penyusunan anggaran yang dilakukan berdasarkan prestasi kerja untuk mendapatkan proses penganggaran yang ekonomis, efisien dan efektif.

Dalam teori keagenan (agency theory) Pemerintah Daerah sebagai agen dalam proses penyusunan APBD dengan inisiatifnya sudah harus menyiapkan rencana pelayanan yang telah direncanakan bersama-sama dengan legislatif, kemudian mengalokasikan anggaran untuk setiap program dan kegiatan berdasarkan prioritas secara efektif, efisien dan dapat 
diukur hasilnya. Jadi dengan perspektif ini yang jadi pokok dari anggaran adalah tujuannya atau misi anggaran tersebut dimanfaatkan. Dalam konsep ini, bahwa setiap output dan outcome sebuah kegiatan yang dilakukan oleh pemerintah akan dihitung kelayakan penggunaan anggarannya. Hal ini akan menimbulkan efisiensi dan rasionalitas dalam pengelolaan anggaran. Ini sesuai dengan konsep Reinventing Government, yang melihat adanya keunggulan penerapan Mission Driven Budgeting (Osborne dan Gaebler, 1992).

Abdullahj et al. (2015:1) mengemuka-kan bahwa perusahaan yang menerapkan standar belanja meningkatkan perencanaan yang memadai, kontrol dan proses pengambilan keputusan di perusahaan. Bahwa standar belanja menghapus produk yang tidak menguntungkan, menyediakan informasi belanja dan pengendalian biaya. Marie et al. (2010) dalam penelitiannya membantah bahwa penggunaan standard costing tidak diperlukan sangat berlebihan. Karena kesederhanaannya, fleksibilitas, dan terjangkau, standard costing tetap menjadi metode belanja favorit akuntansi antara profesi akuntansi dan keuangan di sektor industri dan jasa yang berkembang pesat diseluruh dunia.

Peranan ASB sangat penting dalam proses penganggaran khususnya bagi Pemerintah Kota Kotamobagu jika menerapkan ASB akan mampu membuat pelayanan publik berjalan lebih optimal dan maksimal serta menciptakan organisasi pelayanan publik yang smaller (kecil, efisien), faster (kinerjanya cepat, efektif), cheaper (operasionalnya murah) dan kompetitif.

\section{Faktor-faktor Penghambat}

Dari hasil penelitian yang peneliti lakukan, didapati 6 (enam) faktor penghambat penerapan ASB pada Pemerin-tah Kota Kotamobagu. Ringkasan penelitian dapat dilihat pada tabel 2 halaman 7.

Pertama, dasar hukum. Faktor ini dilihat dari: (1) Pemahaman ASB oleh para ASN ditingkat SKPD dan menganggap bahwa ASB sama dengan standar satuan harga, (2) Sebagian besar TPAD sudah memahami ASB, (3) Belum adanya Model ASB yang baku atau Pedoman Teknis yang mengatur tentang pelaksanaan ASB yang diperkuat dengan peraturan dari Pemerintah Pusat, (4) Tidak adanya peraturan Kepala Daerah yang mengatur tentang penerapan ASB dan tidak ada sanksi dari Pemerintah Pusat bagi Pemda yang tidak menerapkan ASB.

Notoatmodjo (2003) menyatakan bahwa pengetahuan merupakan domain yang sangat penting untuk terbentuknya tindakan seseorang. Pengetahuan diperlukan sebagai dukungan dalam menumbuhkan rasa percaya diri maupun sikap dan perilaku setiap hari, sehingga dapat dikatakan pengeta-huan merupakan fakta yang mendukung tindakan seseorang. Derajat pengetahuan tentang ASB pada Pemerintah Kota Kotamobagu hanya sampai pada tahu (know) dan memahami (comprehension) sehingga kedepan perlu lagi meningkatkan derajat pengetahuan tentang ASB hingga memenuhi derajat kemampuan aplikasi, analisis, sintesis dan evaluasi.

Kelman dalam Azwar (2012:55) membedakan kualitas ketaatan atau kepatuhan terhadap aturan dalam tiga jenis, yaitu: Compliance, Identification dan Internalization. Peraturan berjalan kurang efektif bila derajat ketaatannya hanya berkisar di compliance atau identification saja. Sebaliknya, bila derajat kepatuhannya mencapai internalization, berarti kualitas efektifitas peraturan tersebut sudah sangat tinggi, sehingga sistem berjalan sesuai dengan aturan yang ada tanpa menekankan fungsi kontrol yang ketat. Kepatuhan terhadap hukum, norma-norma dan aturan-aturan membantu memelihara kepercayaan masyarakat kepada pemerintah dalam mengelola keuangan Negara dan meningkatkan kapasitas pemerintah dalam memberikan pelayanan kepada masyarakat. Dengan demikian 
Pemerintah Kota Kotamobagu perlu lagi meningkatkan derajat kepatuhannya pada internalization.

Kedua, ASB tidak efektif dan sulit dipahami. ASB harus dilakukan revisi setiap tahunnya untuk mendapatkan suatu standar belanja yang tepat, juga diperhadapkan dengan program/kegiatan yang ada disetiap daerah itu begitu banyak untuk membuat suatu model belanja untuk program/kegiatan yang menghasilkan output yang sama.

Tabel 2. Faktor-Faktor Penghambat Penerapan ASB pada Kota Kotamobagu

\begin{tabular}{|c|c|}
\hline Rumusan Masalah & Hasil Analisis dan Pembahasan \\
\hline $\begin{array}{l}\text { Apa Faktor-Faktor Penghambat } \\
\text { Penerapan Analisis Standar } \\
\text { Belanja (ASB) Pada } \\
\text { Pemerintah Kota Kotamobagu? }\end{array}$ & $\begin{array}{l}\text { Dari hasil analisis dan pembahasan tentang faktor-faktor penghambat penerapan ASB } \\
\text { pada Pemerintah Kota Kotamobagu yang ditemukan adalah : } \\
\text { 1. Dasar Hukum. } \\
\text { - ASB belum diketahui dan dipahami ditingkat SKPD atau ASN ditingkatan } \\
\text { SKPD menganggap ASB adalah sama dengan SBU } \\
\text { - ASB baru diketahui dan dipahami oleh TAPD } \\
\text { - Tidak ada model baku tentang ASB atau pedoman teknis ASB yang diatur } \\
\text { dengan peraturan perundang-undangan } \\
\text { - Tidak adanya peraturan Kepala Daerah yang mengatur tentang penerapan ASB } \\
\text { dan tidak ada sanksi dari Pemerintah Pusat bagi pemda yang tidak menerapkan } \\
\text { ASB. } \\
\text { 2. ASB Tidak Efektif dan Sulit Dipahami. } \\
\text { - ASB harus direvisi setiap tahun } \\
\text { - ASB manual tidak efektif dan Sulit dipahami. Lebih praktis dalam bentuk } \\
\text { aplikasi } \\
\text { 3. Komunikasi. } \\
\text { - Belum pernah ada sosialisasi tentang ASB oleh karena kurangnya informasi } \\
\text { - Butuh persamaan persepsi antar SKPD } \\
\text { 4.Disposisi atau Sikap. } \\
\text { - Penyusunan RKA-SKPD sudah optimal karena Prinsip ASB telah diterapkan } \\
\text { melalui e-Government dan evaluasi pra-RKA sehingga TAPD merasa tidak } \\
\text { perlu lagi diatur kententuan ASB oleh Pemda } \\
\text { - Tidak ada lagi pembagian Pagu anggaran SKPD (incremental budgeting) karena } \\
\text { anggaran disusun berdasarkan dokumen perencanaan } \\
\text { - Komitmen Pimpinan terhadap peraturan perundang-undangan dan ada } \\
\text { kompromi jika ASB tidak diterapkan maka praktek melaksanakan kebijakan } \\
\text { pimpinan untuk mencari keuntungan masih dapat dilakukan } \\
\text { 5. Sumber Daya Manusia. } \\
\text { - Kualitas SDM ; masih banyak ASN ditempatkan tidak sesuai dengan keahlian } \\
\text { atau latar belakang pendidikan sehingga mengakibatkan ASN kurang paham } \\
\text { - PNan tugasnya. } \\
\text { kurangnya kelum siap menghadapi perkembangan teknologi dan informasi, } \\
\text { - Belum maksimal pelaksanaan bimtek/kursus/diklat untuk pengembangan } \\
\text { kapasitas ASN } \\
\text { 6. Peran TAPD. } \\
\text { - Lemahnya peran TAPD khususnya Bappeda sebagai instansi perencanaan } \\
\text { pembangunan daerah dalam menindaklanjuti penerapan ASB }\end{array}$ \\
\hline
\end{tabular}

Sumber : Data hasil olahan, 2017.

Selanjutnya, ASB dalam bentuk dokumen atau manual textbook tidak efektif dalam penerapannya karena sulit dipahami oleh kebanyakkan ASN, lebih praktis jika ASB sudah disiapkan dalam bentuk aplikasi. Perkembangan sistem informasi yang sudah semakin pesat alangkah baiknya jika ASB yang dikendalikan dalam bentuk Sistem Informasi Akuntansi terkomputerisasi atau lebih tepatnya berbentuk aplikasi software sehingga memudahkan dalam penerapan, penggunaan sumber daya manusia yang tidak terlalu banyak dan lebih efisien dari segi waktu.

Romney dan Steinbart (2006:6) mendefinisikan sistem informasi akuntansi, sebagai berikut: "An accounting information system (AIS) is a system that collects, records, stores, and processes data to produce information for decision makers". Fungsi sistem informasi menurut Romney dan Steinbart (2012) adalah sebagai berikut. (1) Mendukung fungsi dari area bisnis untuk mencapai tujuan yang mencakup bagian keuangan, akuntansi, operasional, 
pemasaran dan sumber daya manusia, (2) Untuk meningkatkan efisiensi dari proses produksi, meningkatkan produktivitas pekerja, memberikan pelayanan dan kepua-san pelanggan, (3) Sebagai sumber utama informasi dan mendukung pengambilan keputusan efektif yang diambil oleh manajer dan profesional bisnis, (4) Untuk mengembangkan produk dan jasa yang kompetitif dan sebagai sebuah keuntungan strategik dalam menghadapi persaingan global, (5) Sebagai komponen utama dalam sumber daya infrastruktur dan kehandalan jaringan bisnis masa kini. Dengan demikian penggunaan ASB berbasis sistem informasi akan sangat mendukung Pemerintah Kota Kotamobagu dalam perencanaan dan pengendalian internal dan menyajikan data yang dimiliki pemerintah lebih cepat, memantau efektivitas regulasi/kebijakan, merencanakan pembangunan daerah secara terpadu serta membantu penerapan good governance serta pelayanan publik yang handal.

Ketiga, komunikasi. Pemerintah Kota Kotamobagu sampai saat ini untuk penerapan ASB tidak didukung oleh adanya proses komunikasi yang efektif dan efisien dari semua pihak yang terkait sehingga informasi yang jelas tentang ASB tidak tersampaikan, akibatnya penerapan ASB sampai saat ini di Kota Kotamobagu belum terwujud. Penerapan akan berjalan efektif apabila ukuran-ukuran dan tujuan-tujuan penerapan dipahami oleh individu yang bertanggung jawab dalam pencapaian tujuan kebijakan. Indikasi yang muncul dari penelitian yang dilakukan peneliti adalah belum ada sosialisasi tentang ASB sehingga banyak ASN kurang mengenal terlebih memahami apa itu ASB oleh karena kurangnya informasi yang dimiliki oleh ASN yang terlibat dalam penyusunan RKA-SKPD dan belum adanya persamaan persepsi antar SKPD terhadap ASB itu sendiri.

Komunikasi menurut Joseph A. Devito dalam Suprapto (2011:5) adalah transaksi, dengan transaksi dimaksudkan bahwa komunikasi merupakan suatu proses di mana komponen-komponennya saling terkait, dan bahwa para komunikatornya beraksi dan bereaksi sebagai suatu kesatuan dan keseluruhan. Menurut Edward III (1980) salah satu variabel yang memperngaruhi implementasi kebijakan yaitu komunikasi (communications). Nugroho (2014:657) mengatakan implementasi kebijakan pada prinsipnya adalah cara agar sebuah kebijakan dapat mencapai tujuannya. Tidak lebih dan tidak kurang. Agar implementasi berjalan efektif, siapa yang bertanggung jawab melaksanakan sebuah keputusan harus mengetahui apakah sebuah implemen-tasi dapat terlaksana.

Setiap proses komunikasi memiliki tujuan untuk efisiensi dan efektivitas. Efisiensi maksudnya adalah dengan sumber daya yang ada, tetap diusahakan sebuah proses komunikasi mencapai hasil yang maksimal. Ketika seorang komunikator menyampaikan pesan, materi pesan yang disampaikan sebisa mungkin mendapatkan feed back yang positif dari penerima pesannya, efektivitas diartikan sebagai cara mengoptimalkan setiap fungsi komponen dalam proses komunikasi. Setiap unsur yang terlibat dalam proses komunikasi, baik itu komunikator, media, pesan, maupun komunikan harus memainkan perannya secara tepat untuk menciptakan iklim yang kondusif sehingga proses komunikasi mencapai tujuannya (Komala, 2009:139-140).

Keempat, disposisi atau sikap. Karakter yang dimiliki oleh para ASN sangat berpengaruh terhadap berhasil tidaknya penerapan atau implementasi kebijakan. Disposisi adalah watak atau karakteristik yang dimiliki oleh implementor, seperti komitmen, kejujuran dan sifat demokrasi. Disposisi atau sikap ini menjadi hal yang diteliti dilapangan terhadap para ASN sebagai impelementor. Hasil yang didapat dalam penelitian ini, penerapan ASB di Kota Kotamobagu dipengaruhi oleh disposisi atau sikap : (1) Penyusunan RKA-SKPD sudah optimal karena Prinsip ASB telah diterapkan melalui e-government dan evaluasi pra-RKA sehingga TAPD merasa tidak perlu lagi diatur kententuan ASB oleh Pemda, (2) tidak ada lagi pembagian Pagu anggaran SKPD (incremental budgeting) karena anggaran disusun berdasarkan dokumen perencanaan dan, (3) Komitmen pimpinan terhadap peraturan 
perundang-undangan dan ada kompromi ASB untuk tidak diterapkan, karena jika ASB diterapkan praktek melaksanakan kebijakan pimpinan untuk mencari keuntungan tidak dapat dilakukan.

Salah satu variabel yang mempengaruhi implementasi kebijakan menurut teori Edward III (1980) adalah sikap atau disposisi implementor. Apabila implementor memiliki disposisi yang baik, maka sebuah kebijakan akan dapat dijalankan dengan baik seperti apa yang diinginkan oleh pembuat kebijakan. Oleh karena itu Dennis A.Rondinelli (1981) pernah mengingatkan bahwa penyebab kegagalan utama dalam melaksanakan orientasi pelayanan publik ini salah satunya adalah adanya sikap keengganan untuk melakukan delegasi wewenang. Sikap merupakan pembawaan yang dapat dipelajari dan dapat mempengaruhi perilaku seseorang terhadap benda, kejadian-kejadian atau makhluk hidup lainnya. Pendapat Azwar (2007) bahwa sikap adalah kecenderungan individu untuk memahami, merasakan, bereaksi dan berperilaku terhadap suatu objek yang merupakan hasil dari interaksi komponen kognitif, afektif dan konatif.

Pada Pemerintah Kota Kotamobagu para implementor memiliki sikap atau perspektif yang berbeda dengan pembuat kebijakan, maka proses implementasi kebijakan juga menjadi tidak efektif yang dipengaruhi oleh situasi dan motivasi.

Kelima, sumber daya manusia (SDM). Faktor penting untuk implementasi kebijakan agar efektif adalah sumber daya. Komponen sumber daya meliputi jumlah staf, keahlian dari para pelaksana, informasi yang relevan, serta cukup untuk menerapkan kebijakan dan pemenuhan sumber-sumber terkait dalam pelaksanaan kebijakan. Dari hasil penelitian dilapangan yang dilakukan oleh peneliti terdapat 3 (tiga) aspek yang sangat berperan menjadi penghambat penerapan ASB di Kota Kotamobagu: (1) kualitas SDM ; masih banyak ASN ditempatkan tidak sesuai dengan keahlian atau latar belakang pendidikan sehingga mengakibatkan ASN kurang paham akan tugasnya, (2) PNS/ASN belum siap menghadapi perkembangan teknologi dan informasi, (3) Belum maksimal pelaksanaan bimtek/kursus/diklat untuk pengembangan kapasitas ASN.

Permasalahan tersebut berdampak pada ukuran kinerja ASN yang ditampilkan menjadi hasil kerja dalam bentuk kualitas maupun kuantitas pada organisasi yang mereka tempati, sehingga dibutuhkan manajemen sumber daya manusia yang baik demi tercapainya tujuan organisasi. Dimensi-dimensi yang dijadikan ukuran kinerja, menurut Nawawi (2000:97) adalah tingkat kemampuan kerja (kompetensi) dalam melaksanakan pekerjaan baik yang diperoleh dari hasil pendidikan dan pelatihan maupun yang bersumber dari pengalaman kerja dan tingkat kemampuan eksekutif dalam memberikan motivasi kerja. George C. Edward III (1980), mengatakan variabel yang mempengaruhi implementasi kebijakan sumber daya (resources), salah satunya SDM. SDM adalah faktor penting untuk implementasi kebijakan agar efektif. SDM yang tidak memadai (jumlah dan kemampuan) berakibat tidak dapat dilaksanakannya kebijakan secara sempurna serta tidak mampu melakukan pengawasan dengan baik. Jika jumlah staf pelaksana kebijakan terbatas, maka hal yang harus dilakukan adalah meningkatkan kemampuan/keterampilan para pelaksana untuk melakukan penerapan kebijakan. Untuk itu, Pemerintah Kota Kotamobagu khususnya ASN perlu ada manajemen SDM yang baik agar dapat meningkatkan kinerjanya.

Komitmen sumber daya manusia ditentukan oleh manajemen sumber daya manusia yang memiliki pengembangan karier kerja sesuai dengan sikap, pengetahuan, keterampilan dan keahlian dalam menghadapi dinamika kerja yang terus bergerak maju dan kompetitif menghadapi berbagai kesenjangan dan permasalahan suatu organisasi kerja.

Keenam, peran TAPD. Tim Anggaran Pemerintah Daerah (TAPD) adalah tim yang dibentuk dengan keputusan kepala daerah dan dipimpin oleh Sekretaris Daerah yang mempunyai tugas menyiapkan serta melaksanakan kebijakan kepala daerah dalam rangka 
penyusunan APBD yang anggotanya terdiri dari pejabat perencana daerah, Pejabat Pengelola Keuangan Daerah dan pejabat lainnya sesuai dengan kebutuhan Peraturan Pemerintah Nomor 58 Tahun 2005 Pengelolaan Keuangan Daerah dan Permendagri Nomor 13 Tahun 2006 tentang Pedoman Pengelolaan Keuangan Daerah sebagaimana diubah terakhir dengan Permendagri Nomor 21 Tahun 2011.

Peranan TAPD sangat strategis karena membantu kepala daerah menyusun kebijakan dan mengkoordinasikan penyelenggaraan urusan pemerintahan daerah termasuk pengelolaan keuangan daerah. Perencanaan dan penganggaran merupakan proses yang terintegrasi, oleh karenanya output dari perencanaan adalah penganggaran (Bastian 2009:10). Pada Pemerintah Kota Kotamobagu pejabat perencana diwakili oleh Kepala Bappeda sebagai bagian dari TAPD, dimana dalam pelaksanaannya Bappeda sebagai lembaga koordinasi perencanaan penganggaran didaerah masih mengalami keterbatasan melaksanakan perannya melakukan kajian dalam perencanaan penganggaran khususnya penerapan ASB. Pembahasan sebelumnya diungkapkan bahwa Bappeda sudah melakukan kerja sama dengan salah satu perguruan tinggi untuk mengakaji ASB dan sekarang produk ASB dari hasil kajian yang dikerjasamakan, hanya saja dalam penerapan ASB tersebut belum dilakukan.

ASB sebagai administrasi publik belum diterapkan oleh Pemerintah Kota Kotamobagu yang berkenaan dengan implementasi kebijakan publik. Administrasi publik didefinisikan oleh Nugroho (2014:174) sebagai koordinasi dari upaya individu dan kelompok untuk menjalankan kebijakan publik yang berarti menyangkut kegiatan sehari-hari sebuah pemerintahan (government). Upaya untuk mewujudkan birokrasi yang bersih, akuntabel dan transparan hanya dapat dilaksanakan apabila kita memiliki kemampuan kepemimpinan birokrasi yang baik dalam meningkatkan pelayanan kepada publik, kepemimpinan birokrasi yang mampu berinteraksi dan berkomunikasi dengan seluruh lapisan masyarakat adalah wujud kepimpinan birokrasi yang diperlukan dalam mewujudkan good governance. Menurut Rogers dan Svenning dalam Susanto (2016:11), kepemimpinan adalah suatu kemampuan bertindak dan berkomunikasi untuk mempengaruhi orang lain sesuai dengan jalan yang diinginkan untuk mencapai tujuan yang telah ditetapkan.

Dalam rangka implementasi ASB sebagai bagian dari administrasi publik diperlukan peran kepemimpinan birokrasi yang kuat. Aspek leadership dalam birokrasi pemerintahan merupakan suatu perangkat penting yang tidak dapat dipisahkan dalam suatu struktur organisasi pemerintahan, sehingga setiap elemen dalam struktur pemerintah dapat digerakkan sesuai dengan fungsi dan spesialisasinya.

\section{Penutup}

Kesimpulan penelitian adalah Pemerintah Kota Kotamobagu hanya menerapkan prinsip-prinsip ASB dalam penganggaran dan ASB belum diatur lewat Peraturan Kepala Daerah sebagaimana amanat Undang-Undang sehingga Kota Kotamobagu belum tertib dalam administrasi penganggaran daerah dan Peneliti menemukan 6 (enam) faktor-faktor penghambat penerapan ASB yaitu dasar hukum, ASB tidak efektif dan sulit dipahami, komunikasi, disposisi atau sikap, sumber daya manusia dan peran TAPD.

Saran yang dapat diberikan dari penelitian ini : (1) Proses penganggaran secara efektif dan efisien menghasilkan 3 (tiga) kali opini WTP atas Laporan Keuangan Pemerintah Daerah dari BPK, tetapi akan lebih optimal lagi proses penganggaran Pemerintah Kota Kotamobagu jika ASB sudah diatur lewat Peraturan Kepala Daerah dan dari sisi administrasi akan lebih baik lagi, (2) Dari perspektif komitmen normatif, organisasi publik harus patuh kepada peraturan/hukum dan berkomitmen menjalankannya dalam menjaga konsistensi perilaku organisasi dalam pencapaian tujuan organisasi publik, (3) Penggunaan ASB berbasis sistem 
informasi akan sangat membantu pemerintah dalam meningkatkan menyajikan data yang dimiliki pemerintah lebih cepat, memantau efektivitas regulasi/kebijakan, merencanakan pemba-ngunan daerah secara terpadu serta membantu penerapan good governance serta pelayanan publik yang handal, (4) Perlu adanya komunikasi aktif oleh TAPD kepada seluruh implementor dalam hal ini SKPD penyusun anggaran sehingga informasi tentang ASB dan penerapannya tidak hanya terbatas pada TAPD saja tapi tersampaikan kepada semua pihak terkait, (5) Perlunya disposisi atau sikap yang baik untuk menerima/setuju dengan penerapan ASB dan melaksanakannya dengan senang hati serta didukung oleh komitmen dan sikap demokrasi dari pimpinan yang berorientasi pada pelayanan publik, (6) Perlunya adanya metode peningkatan kapasitas SDM kepada ASN sebagai implementor melalui Bimtek/Diklat/Kursus khususnya dalam penerapan ASB serta harus didukung manajemen ASN yang baik dalam menempatkan seseorang sesuai dengan latar belakang pendidikan dan keahliannya dalam rangka continuous improvement, (7) TAPD perlu memperjelas hak dan kewajiban semua anggota sesuai dengan kedudukannya melalui penjabaran tugas kerja masing-masing anggota (job description), agar TAPD memiliki peran maksimal termasuk peran Bappeda sebagai lembaga yang mengkoordinasikan perencanaan penganggaran didaerah dan perannya melakukan kajian dalam perencanaan penganggaran khususnya penerapan ASB.

\section{Daftar Pustaka}

Tanjung, Abdul Hafiz. 2010. Peranan Dan Teknik Penyusunan Analisis Standar Belanja Dalam Penyusunan APBD. Penyusunan Standar Biaya Kabupaten Pelalawan. Riau.

Karim, Tarmizi A. 2016. Materi : Kebijakan Pengawasan Penyelenggaraan Pemerintahan Daerah Pada Aspek Anggaran, PBJ Dan Dana Desa. Inspektur Jenderal Kementerian dalam Negeri. Jakarta.

Nabila. 2014. Pelaksanaan Anggaran Berbasis Kinerja di Jawa Timur. Jejaring Adminstrasi Publik. Tahun VI. No.2 Juli-Desember 2014. FISIP UNAIR.

Maharshiyam, Sulaiman. 2015. Identifikasi Faktor-Faktor Penghambat Penerapan Analisis Standar Belanja (ASB) Di Pemerintah Kota Malang. Universitas Brawijaya. Malang.

Creswell, John W. 2012. Educational research : planning, conducting, and evaluating quantitative and qualitative research. 4th ed. p. cm. Pearson. University of NebraskaLincoln.

Ibrahim. 2015. Metodologi Penelitian Kualitatif ; Panduan Penelitian beserta Contoh Proposal Kualitatif. Perpustakaan Nasional: Katalog dalam Terbitan. Pontianak.

Satori, Djam'an dan Aan Komariah. 2014. Metodologi Penelitian Kualitatif. Alfabeta. Bandung.

Musfiqon. 2012. Panduan Lengkap Metodologi Penelitian Pendidikan. PT. Prestasi Pustakaraya. Jakarta.

Osborne, David and Ted Gaebler 1992, Reinventing Government. Plume 1993. New York.

Abdullahj, Sadiq Rabin, Iyanuoluwa Oni, Muhammed Dahiru Ahmeb dan Faruk Imam Shakur. (2015). Effects Of Standard Costing On The Profitability Of Telecommunication Companies (Study Of MTN Nigeria). International Journal of Management and Commerce Innovations. Volume 3. Issue 1, pp: (292-297). University Kano.

Marie, Attiea. Walid Cheffi, Rosmy Jean Louis, Dan Ananth Rao. (2010). Is Standard Costing Still Relevant? Evidence from Dubai. Management Accounting Quarterly Winter. Volume 11. Nomor 2.

Notoatmodjo, S. 2003. Pendidikan dan Perilaku Kesehatan. Jakarta : Rineka Cipta. 
Azwar, S. 2007. Sikap Manusia Teori dan Pengukurannya. Edisi 2. Yogyakarta : Pustaka Pelajar.

Romney, Marshall B. dan Steinbart, Paul J. 2012. Accounting Information Systems. Boston: Pearson Education.

Suprapto, Tommy. 2011. Pengantar Ilmu Komunikasi. Yogyakarta: CAPS.

Edward, George C. III. 1980. Implementing Public Policy. Washington DC: Congresional, Quartely Press.

Nugroho, Riant. 2014. Public Policy. Teori, Manajemen, Dinamika, Analisis, Konvergensi, dan Kimia Kebijakan. PT. Elex Media Komputindo. Kelompok Gramedia. Jakarta.

Komala, Lukiati. 2009. Komunikasi Massa. Jakarta : Penerbit Simbiosa Rekatama Media.

Rondinelli, Dennis A. 1981. Government Decentralization In Comparative Perspective Theory and Practice In Developing Countries: International Review Of Administrative Scines.

Nawawi, Hadari. 2000. Administrasi Personel Untuk Peningkatan Produktivitas Kerja. Jakarta. Haji Intermedia.

Bastian, Indra. 2006. Sistem Akuntansi Sektor Publik. Edisi 2. Salemba Empat: Jakarta.

Susanto, Eko Harry. (2016). Komunikasi dan Gerakan Perubahan : Kemajemukan Dalam Konstelasi Sosial, Ekonomi, Politik, Jakarta : Penerbit Mitra Wacana Media. 